\title{
Estimation of the banking sector competition in the CEE countries: The Panzar-Rosse approach ${ }^{*_{1}}$
}

\author{
Arben Mustafa ${ }^{2}$, Valentin Toçi ${ }^{3}$
}

\begin{abstract}
Competitive conditions in the banking sectors in the light of transition process in the Central and Eastern Europe countries (CEE) has been subject of interest for researchers and policy-makers, especially upon entry of foreign banks and concentrated markets. In this paper the Panzar-Rosse approach is used to assess competition of banking sectors in CEE. By using General Method of Moments on the panel data for 300 banks for the period 1999-2009, empirical evidence indicates that banks operating in the CEE exert monopoly behaviour. From the methodological point of view, the findings suggest that using a price equation or controlling for total assets in a Panzar-Rosse approach produces upwards biased and invalid estimates of the H-statistic. Therefore, further support is provided for maintaining a reducedform revenue equation when estimating a Panzar-Rosse model. The findings also suggest that banks operating in the non-EU countries of the CEE region have exerted stronger market power compared to the banks operating in the EU countries of this region. Policy-makers should improve competitive conditions and general 'enabling' environment for the banking sectors, especially the non-EU countries of the CEE region, while balancing competition-stability trade-off.
\end{abstract}

Key words: banks, competition, Panzar-Rosse approach, Central and Eastern Europe

JEL classification: $G 21, D 4, P 2$

\footnotetext{
* Received: 7-03-2017; accepted: 21-12-2017

1 Acknowledgement: We would like to thank Geoffrey Pugh, Iraj Hashi, two anonymous referees and participants at the 1st International Conference "Smart Ideas and a New Concept of Economic Regeneration in Europe" - SINCERE, Dubrovnik, Croatia 28th September - 1st October 2016, for useful comments. The views in this paper are solely the responsibility of the authors and should not be interpreted as reflecting the views of the institutions they are affiliated with.

2 Assistant Professor, University "Kadri Zeka" Gjilan, Faculty of Economics, 60000 Gjilan, Republic of Kosovo and CERGE-EI Teaching Career Integration Fellow. Scientific affiliation: macroeconomics, financial economics, banking. Phone: +377 44376 555. E-mail: arben. mustafa@uni-gjilan.net.

3 Associate Professor, University of Prishtina "Hasan Prishtina", Faculty of Economics, 10000 Prishtina, Republic of Kosovo. Scientific affiliation: financial economics, banking, institutional economics. Phone: +377 44376 907. E-mail: valentintoci@gmail.com (corresponding author).
} 


\section{Introduction}

Before the transition process, the banking system in most CEE countries was characterized by monobank systems. For example, in ex-Yugoslavia, each republic had a few banks that operated in different segments consistent with the central planning of the economy. Overall, banking system competition in the CEE countries may be considered to have been inexistent or highly limited. In most countries, the transition from the monobank system into the two-tier banking system produced concentrated market structures. This due to the inheritance of asset portfolios by a single bank, or a few banks. In addition, the entry of foreign banks was limited in early years of the transition process. The degree of financial intermediation was very low, while the interest rate spreads were high (World Bank, 2016). This surrounding environment was key for banks operating in concentrated markets and exert market power. However, the banking reforms consisting of the privatization of the state-owned banks and the elimination of barriers to entry for foreign banks, resulted in a large number of foreign banks entering the markets in CEE. The entry of foreign banks is considered to have been fundamental to the development of modern banking systems in this region and induced the banking system competition by bringing capital, know-how and technology into these markets (Bonin et al., 1999; Tang et al., 2000). The CEE countries recorded some progress in developing competition policy and institutions, but the progress was slow and most of the CEE countries lag behind the more advanced countries of the Euro Area. Hence, the aim of this paper is to estimate the degree of banking system competition in the CEE countries. This will enable an assessment of the hypothesis 'whether banking sectors were transformed into competitive markets or still exert high market power'.

Although rich body of the literature measures competition in banking, there is no general agreement which is the most appropriate method. However, the approach developed by Panzar and Rosse (1987), which directly quantifies the competitive behaviour, has been largely recognized as a more appropriate approach compared to the structural methods. Based on this approach, competition is measured by the elasticity of bank revenues to the change of input prices, which indicates whether the competitive behaviour of banks is consistent with monopoly, monopolistic competition, or perfect competition.

In this paper, the Panzar-Rosse method is used to estimate banking system competition in 16 CEE countries for the period 1999-2009. ${ }^{4}$ Moreover, interaction terms are used to test the hypothesis whether the degree of banking sector

\footnotetext{
4 The countries included in this study are: Albania, Bosnia and Herzegovina, Bulgaria, Croatia, the Czech Republic, Estonia, Hungary, Latvia, Lithuania, Macedonia, Montenegro, Poland, Romania, Serbia, Slovakia, and Slovenia.
} 
competition in the non-EU countries differs from the degree of competition in the EU members of the CEE region. Unlike most of the other studies in the CEE countries context, this paper follows Bikker et al. (2012; 2007). The authors suggest not to scale the dependent variable to total assets and not to include total assets as an explanatory variable in a Panzar-Rosse model. By doing so, it is aimed at eliminating the misspecification bias that is present in most of the studies that have applied the Panzar-Rosse approach. Another model specification issue for the Panzar-Rosse model is related to the choice between total revenues and interest revenues to be used as dependent variables. The regression using each of these variables is estimated in order to check if they produce consistent results. The estimation of the Panzar-Rosse regression is conducted on dynamic panel data using the General Method of Moments (GMM).

To summarize, the main hypothesis of this study is to estimate if the banking sector in the CEE countries exerts monopoly behaviour. In addition, the hypothesis if there are differences in the competitive behaviour of the banks between the EU and nonEU member countries of the CEE region is tested. Another important objective of this study is to test the hypothesis of Bikker et al. (2012; 2007). Authors claim that the scaling of the dependent variable to total assets or controlling for total assets in a Panzar-Rosse model produces an upwards biased and always positive $\mathrm{H}$-statistic. This may be considered a misspecification problem of the model. Lastly, we aim to check whether the choice between using total income or interest income as a dependent variable makes a significant difference to the results produced by the Panzar-Rosse model. ${ }^{5}$

This paper is organized as follows. In the next section, a theoretical background on the approaches used to measure competition and a brief review of empirical literature in the CEE countries is presented. In section 3 the model and methodology is described. In section 4 the empirical data and the analysis are presented. In section 5 estimation results and findings are discussed. Section 6 concludes.

\section{Literature review}

Banking system competition is generally viewed as the driving force for the development of an efficient banking system. The relevance of competition, however, is related also to its potential role in the stability of the banking system - with the mainstream view claiming that competition leads banks to higher risktaking. The interest of both, academics and policy-makers in banking sector, the competition has been reignited by the recent global financial crisis. Many believe

\footnotetext{
5 Relating competitive behaviour of banks with their risk-taking appetite and pricing is important, but falls beyond the scope of the paper. For these relationships see Mustafa (2014).
} 
that competition has contributed to the incidence of the crisis. However, in spite of its high importance for the banking system and the economy as a whole, the literature still has not come to a general agreement on the most appropriate method for measuring competition. The literature in this field is divided into two major streams, consisting of structural and non-structural approaches.

The structural approach for the measurement of competition mainly relies on the Structure-Conduct-Performance (SCP) paradigm. This approach relates competition to the degree of market concentration. The SCP paradigm originates from the work of Bain (1951), where he analysed firms' performance in 42 industries in the US during the 1930s. The results of this study suggested that firms operating in more concentrated industries with higher entry barriers generated higher rates of return. On the other hand, firms operating in less concentrated industries and those with lower entry barriers generated lower rates of return. These findings were interpreted as evidence for the SCP paradigm. In its original form, the SCP paradigm maintains that an exogenous market structure influences the conduct of banks and their performance. More specifically, the SCP paradigm claims that a higher degree of concentration grants market power to incumbent firms. This enables firms to behave in particular ways, such as colluding with each other and resulting in higher profits. However, in most of the studies dealing with the SCP paradigm, firms' conduct is not explicitly taken into account. Therefore, it is rather the structure-performance relationship which is explored and a particular type of conduct or behaviour is only assumed.

Despite its extensive use in the literature, the SCP paradigm has been subject to criticisms that contest its ability to explain the competitive conditions in a market. The most important criticism is the assumed one-way causality from market structure to conduct and then to performance. According to Vesala (1995), market structure and conduct are endogenously determined. More specifically, it is unreasonable to exclude the feedback effects from potential strategic behaviour of firms, i.e. the conduct of firms, to the market structure. One of the most widely reported critiques to the SCP approach is represented by the Efficiency Structure hypothesis which was developed by Demsetz (1973). Similar to the SCP, the efficiency structure hypothesis is a structural approach, but often referred as the alternative of the SCP paradigm. This view claims that higher profits of firms operating in concentrated markets are a result of the superior efficiency of larger firms deriving from economies of scale and not from the market power. Another important view that criticizes the SCP paradigm is the Contestability Theory, developed by Perrakis et al. (1982) and Baumol (1983). According to this theory, firms behave competitively also in a concentrated industry or even in a monopoly if the market is contestable - perfectly contestable markets are those that are characterized by free entry and costless exit.

These critiques led to the development of the non-structural approaches which do not take into account the structural features of the market when measuring 
competition. The most commonly used non-structural approach is represented by the method of Panzar and Rosse (1987), hereafter referred as the P-R method, which is a non-structural approach, grounded in the microeconomic theory. This method measures competition by directly quantifying the conduct of firms and not taking into account the market structure. In assessing competition, the focus of the P-R method is on the competitive behaviour of firms rather than on market structure, implying some similarity between this approach and the contestability theory. Some studies, such as Bandt and Davis (2000), Nathan and Neave (1989) and Yildirim and Philippatos (2007) use the P-R approach to test the contestability theory by measuring the competitive behaviour of banks in markets characterized by a high degree of concentration. The non-monopoly behaviour of banks found in these markets supports the predictions of the contestability theory, according to which a concentrated market can be characterized by competitive behaviour if there is a credible threat of entry by new entrants.

The P-R method has previously been applied in a number of studies that have investigated banking sector competition. A number of empirical studies such as Bikker and Groenveld (1998), Bikker and Haaf (2002), Casu and Girardone (2006), Hahn (2008), Staikouras and Fillipaki (2006) have used the Panzar-Rosse approach to estimate banking sector competition in the EU countries for different period of times and generally found that the competitive behaviour was consistent to monopolistic competition. Similar results were found also by Apergis (2015), who used this approach to estimate banking sector competition in a set of 21 emerging market economies for the period 2002-2012. Several authors have used the P-R approach to measure the degree of competition in the banking sectors of the CEE countries. Yildirim and Philippatos (2007) used this method to estimate banking sector competition in the CEE countries for the period 1993-2000 and found that the banking systems of these countries were characterized by monopolistic competition. Similar results were found also by Mamatzakis et al. (2005) who estimated banking sector competition in the SEE countries for the period 19982002, and Delis (2010) who covered the CEE countries for the period 19992006. More diverse results were found by Delis (2010) who used this approach to measure the degree of banking sector competition in 22 individual CEE countries for the period 1999-2006. The author found that the competitive behaviour varied between monopoly and monopolistic competition through the sample of countries, with the highest market power noted in Kazakhstan and the lowest in Poland. More recently, Memic (2015) used the Panzar-Rosse approach to estimate banking sector competition in Bosnia and Herzegovina and found that the competitive behaviour of banks operating in these countries was consistent to monopoly or perfectly collusive oligopoly.

Another widely used approach that does not take into account the structural features of the market when measuring the degree of market power is the Lerner Index. The 
Lerner Index measures the mark-up of price over the marginal costs for each bank. Higher values of the index indicate a higher degree of market power being exerted by the investigated banks.

A recently developed non-structural method for the measurement of competition is the Boone Indicator, introduced by Boone (2008). The Boone Indicator estimates the degree of competition based on the idea that competition increases the market shares of more efficient firms and reduces the market shares of inefficient firms. In this context, the larger the impact of efficiency on the increase of firms' market shares, the higher is considered to be the degree of competition in that market and vice versa. Kasman and Carvallo (2014) have used the Boone Indicator to assess banking system competition for a sample of Latin American and Caribbean countries over the period 2001-2008.

\section{Model and methodology}

The P-R method produces the so-called H-statistic which measures the sum of elasticities of bank's revenues with respect to input prices. In other words, the $\mathrm{H}$-statistic indicates how a bank's revenues respond to an increase of input prices. The value of the H-statistic indicates whether the conduct of banks is in line with the notion of monopoly, monopolistic competition, or perfect competition.

The basic model for estimating a P-R model is presented in equation 1:

$$
\begin{aligned}
& \ln \left(\text { rev }_{i}\right)=\alpha_{0}+\beta_{1} \ln \left(\text { fundingcosts }_{i}+\beta_{2} \ln \left(\text { labourcosts }_{i}+\right.\right. \\
& +\beta_{3} \ln (\text { physicalcapitalcosts })_{i}+\sum_{i=1}^{n} \gamma_{i} \delta_{i}+\varepsilon
\end{aligned}
$$

where, $i$ indexes the banks; rev represents the bank revenues; fundingcosts, labourcosts and physicalcapitalcosts represent the input prices; $\delta$ is a vector of control variables; and $\varepsilon$ represents the error term. The sum of the elasticity coefficients of the bank revenues with respect to the changes of input prices $\left(\beta_{1}+\beta_{2}+\beta_{3}\right)$ produces the H-statistic. That explains whether banks' competitive behaviour is in line with monopoly $(\mathrm{H} \leq 0)$, monopolistic competition $(0<\mathrm{H}<1)$ or perfect competition $(\mathrm{H}=1)$.

A smaller or equal to zero $\mathrm{H}$-statistic $(\mathrm{H} \leq 0)$ implies that the increase of input prices leads to a decline of bank revenues which implies that the competitive behaviour of the banking system is in line with monopoly. An H-statistic of between zero and one $(0<\mathrm{H}<1)$ corresponds to monopolistic competition, implying that an increase of input prices leads to a less than proportional increase of the bank revenues. The banking system is considered to be operating in perfect competition when the $\mathrm{H}$-statistic equals one $(\mathrm{H}=1)$, implying that an increase of input prices leads to a proportional increase of bank revenues. 
One of the key assumptions upon which the P-R model is built is that banks are operating in long-run equilibrium. To test whether the banking market is operating in long-run equilibrium, previous studies using this approach have estimated a regression similar to equation 1, but using Return on Assets (ROA) as the dependent variable. The model produces an $\mathrm{H}_{\mathrm{ROA}}$ that is the sum of $\beta_{1}+\beta_{2}+\beta_{3}$, which represents the sum of the elasticities of bank profitability with respect to the input prices. The market is considered to be operating in long-run equilibrium when $\mathrm{H}_{\mathrm{ROA}}=0$, thus implying that in the long-run equilibrium bank profitability is not statistically correlated with input prices (De Rozas, 2007). However, Bikker et al. (2012) claim that $\mathrm{H}_{\mathrm{ROA}}$ must not necessarily equal zero if the market is in structural equilibrium but under imperfect competition. In this view, when the market demand is characterized by some degree of elasticity, the monopolist will not be able to pass the entire increase of costs to the customers and $\mathrm{H}_{\mathrm{ROA}}$ will be negative.

The estimation is conducted using the system General Method of Moments (GMM) dynamic panel estimator, which was initially developed by Arellano and Bond (1991) and extended by Arellano and Bover (1995) and Blundell and Bond (1998). The "system" GMM estimates the model by creating a system of two equations for each time period, where one equation is a first-order differenced model instrumented by lagged levels as in Arellano and Bond (1991). In the second equation variables are held in their original levels and instrumented with lags of their own first differences. By using the GMM method to estimate our model, we follow Goddard and Wilson (2009) who suggest that the Panzar-Rosse revenue equation should be estimated using the GMM method in a dynamic formulation, claiming that the adjustment towards market equilibrium is partial rather than instantaneous.

In order to ensure that our model does not suffer from misspecification issues, we have run a number of diagnostic tests. The diagnostic tests in the GMM approach start with the tests on the validity of instruments. The instrument validity test can be performed in two ways: a) Arellano-Bond tests for first-order and secondorder serial correlation in the residuals; and b) the Sargan test of over-identifying restrictions.

The Arellano and Bond (1991) GMM estimator requires that there is no secondorder serial correlation in the error term of the first-order differenced model. In our case, this requirement is satisfied given that the null hypothesis of no second-order serial correlation cannot be rejected. Therefore, the instruments are valid. However, for this test to be reliable the model should have first-order autocorrelation in the differenced error terms. This implies that errors in levels do not follow a random walk. The null hypothesis that there is no first-order serial correlation in the error term can be rejected at the $1 \%$ level of significance, suggesting that the test for second-order serial correlation in our regression is reliable. 
The other tests on the validity of instruments are represented by the Sargan test and Hansen test, which test whether the overidentifying instruments are uncorrelated with the error term. The Sargan test is not robust to the presence of heteroscedasticity and autocorrelation, whereas the Hansen test is robust to both and, as such, is considered to be more reliable (Roodman, 2005). In our case, the Sargan test rejects the null hypothesis that the instruments are uncorrelated with the error term, but the hypothesis is not rejected by the Hansen test with a p-value of 0.402. While the Hansen test is preferred, it can be weakened (i.e. its ability to reject the null hypothesis of validity of overidentifying instruments) in the presence of "too many instruments" (Roodman, 2009). The presence of this problem is shown by a p-value close to 1 . However, this does not appear to be a problem in our regressions.

The Hansen test statistics can be used also to test the validity of subsets of instruments through the Difference-in-Hansen tests of exogeneity of instrument subsets. In this regard, we test for the joint validity of the differenced instruments used for the level equation. The test results suggest that the null hypothesis that differenced instruments are valid may not be rejected ( $p$-value $=0.389$ ), hence providing support to the choice of the "system" GMM against the "differenced" GMM to estimate our equation.

Another concern related to the specification of panel data models has been raised by Sarafidis et al. (2009), who claim that panel data are likely to suffer from crosssectional dependence, which may arise due to spatial dependence, economic distance and common shocks. In order to tackle this problem, we have followed the conventional method of including year dummies in the model. However, Sarafidis et al. (2009) claim that the inclusion of time dummies may not be sufficient to tackle the problem of cross-sectional dependence. These authors suggest that the above tests of instrument validity may be indicative for the presence of a cross-sectional dependence problem. In this regard, our results that there is no evidence of secondorder serial correlation in the residuals may imply that there is no heterogeneous error cross-section dependence.

Given that one of the main assumptions of P-R model for the measurement of competition is that markets are in long-run equilibrium, we have investigated this by estimating equation 2 with the return on assets (ROA) as the dependent variable. ${ }^{6}$ The estimation provided an $\mathrm{H}_{\mathrm{ROA}}$ coefficient (measuring constant elasticity) of -0.01 , which can be considered as very close to zero and, hence, makes the P-R model applicable for our sample of data. The fact that the joint impact of the input prices on the ROA is statistically different from zero might raise concerns on whether the market is in long-run equilibrium. However, taking into account the suggestion of Bikker et al. (2012) that $\mathrm{H}_{\mathrm{ROA}}$ must not necessarily equal

\footnotetext{
${ }^{6}$ In line with Claessens and Laeven (2004), the measure of ROA is expressed as $\ln (1+\mathrm{ROA})$ in order to adjust for potential negative values that might have occurred due to bank losses in any year.
} 
zero if the market is in structural equilibrium but under imperfect competition, we consider that the P-R approach is applicable to our sample of data. In addition, the introduction of dynamics in our model enables a gradual adjustment towards the long-run equilibrium.

\subsection{Model specification}

The P-R model used in this paper is in line with most of the studies that have used the this model to measure banking sector competition, with some modifications related to the control for banks' size. In addition, among the control variables, macroeconomic and institutional variables are included to control for country-level factors that might have an impact on bank revenues. The model has the following form:

$$
\begin{aligned}
& \ln \left(\text { int_int_real } i_{i t}\right)=\alpha_{0}+\beta_{1} \ln \left(\text { int_inc_reali } i_{t-1}\right)+\beta_{2} \ln \left(p \text { funds } s_{i t}\right)+ \\
& +\beta_{3} \ln \left(p_{\text {_labour }}\right)+\beta_{4} \ln (\text { p_physcapital } i t)+\beta_{5} \text { equity_ta }_{i t}+ \\
& +\beta_{6} \text { loans_ta }_{i t}+\beta_{7} \text { prov_loans } i t+\beta_{8} \text { rgdp_growth }{ }_{i t}+\beta_{9} \text { ebrd_bankref } f_{i t}+
\end{aligned}
$$

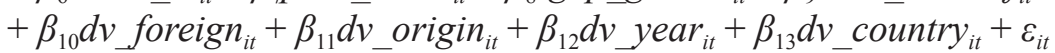

where, $i=1 \ldots 294$ indexes the banks; and $t=1999 \ldots 2009$ indexes the years.

Table 1: Description of variables

\begin{tabular}{|l|l|}
\hline \multicolumn{1}{|c|}{ Variable } & \multicolumn{1}{c|}{ Description } \\
\hline int_inc_real & interest income adjusted to inflation \\
\hline p_funds & interest expenses / total funding \\
\hline p_labour & personnel expenses / total assets \\
\hline p_physcapital & other operating expenses / fixed assets \\
\hline loans_ta & total loans / total assets \\
\hline prov_loans & loan-loss provisions/total loans \\
\hline equity_ta & equity / total assets \\
\hline Rgdpgrowth & real GDP growth rate \\
\hline ebrd_bankref & EBRD index of banking reform \\
\hline dv_foreign & dummy variable for foreign ownership \\
\hline dv_origin & dummy variable for the country-of-origin of the bank (1 for EU-12 or US) \\
\hline dv_year & dummy variables for years \\
\hline dv_country & dummy variables for country \\
\hline
\end{tabular}

Source: Authors

One of the issues that must be considered when specifying a model like this is the choice of the dependent variable to represent bank revenues. Most studies have used interest income as the dependent variable. Some studies have used 
total income as the dependent variable considering that non-interest income was continuously increasing its share in the total income. Given that the banking sectors of the CEE countries are mainly concentrated in the traditional banking activities, where interest income largely dominates the overall structure of bank revenues (on average $73 \%$ of total revenues ${ }^{7}$ ), the dependent variable in our main model specification is the interest income (int_inc_real). Nevertheless, we run a separate regression also with the total income (tot_inc_real) as the dependent variable in order to check if the results are consistent.

The decision to use the absolute value of the interest income and total income as dependent variables, rather than scaling them to total assets which has been practiced by most of the studies, is based on Bikker et al. (2007). The authors claim that the scaling the income variable to total assets misspecifies the P-R model. According to this view, by scaling the income variable (both interest and total income) to total assets and by including total assets among the control variables, transforms the revenue equation into a price equation. Using a price variable instead of revenues as the dependent variable produces an $\mathrm{H}$-statistic that measures the elasticity of prices with respect to input prices, rather than the elasticity of revenues to input prices. Hence, the derived H-statistic will be positive even when the market is characterized by monopoly behaviour, because the monopoly price is an increasing function of the marginal cost. This means that scaling the dependent variable (interest income or total income) to total assets will always produce a positive $\mathrm{H}$-statistic, implying that monopoly will always be rejected. In order to test the hypothesis of Bikker et al. (2007), separate regressions are run to test if and how the $\mathrm{H}$-statistics produced from the regressions with an unscaled dependent variable differ from the regressions that use a scaled dependent variable.

The selection of the variables for the input prices follows the intermediation approach (Sealey and Lindley, 1977). This approach treats banks as firms that produce loans by using deposits and other loanable funds, labour, and capital as inputs. Therefore, in line with most of the studies applying the P-R model to measure banking competition, input prices in our model consist of three categories:

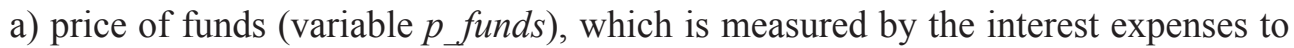
total funds ratio; $\mathrm{b}$ ) price of labour (variable $p_{-}$labour), which is measured by the ratio between personnel expenses and total assets; and c) price of physical capital (variable $p$ _physcapital), which is measured by the other operating expenses to fixed assets ratio. Although the list of input prices variables is based on a standard and traditional exposition of input prices following the intermediation approach, it should be noted that the underlying assumption is uniform banking technology. Modern banking model should be revisited to take into account advances in banking

\footnotetext{
7 Based on own calculations by using the data from the Fitch-IBCA Bankscope database.
} 
business and the digital economy. However, data limitations often pose a problem in revising the representation of inputs and outputs (and pricing) in banking business, which may be one of the reasons why the studies using the Panzar-Rosse approach still stick to this definition of bank inputs.

The input prices represent the variables of the main interest in our model. The sum of their coefficients will produce the $\mathrm{H}$-statistic, which is our measure of competition. In line with the literature in this field, the dependent variable (int inc real) and the variables on the input prices ( $p_{-}$funds, $p_{-}$labour, and $p_{\text {_ physcapital }}$ ) are transformed into natural logarithms in order for the coefficients of the input prices to be interpreted as constant elasticities.

A number of variables are included to control for bank-specific features that may affect bank revenues. The bank-specific control variables include the loans to total assets ratio (loans_ta), the equity to total assets ratio (equity_ta), and the quality of the loan portfolio measured through the loan-loss provisions to total loans ratio (prov_loans). In line with Bikker et al. (2012), the regression does not contain total assets as an explanatory variable to control for bank's size. According to Bikker et al. (2012), the inclusion of total assets among the explanatory variables entails the same bias as the scaling of the dependent variable to total assets. This transforms the reduced-form revenue equation into a price equation. In order to test the hypothesis of Bikker et al. (2012), a separate regression is run in which the total assets $(\log t a)$ variable is included, to check whether and how the H-statistic differs from the regressions run without controlling for total assets.

The regression controls also for the potential impact of the macroeconomic environment on banks' revenues, by including the real GDP growth (rgdpgrowth). In addition, the regression controls also for the impact of banking reform, using the EBRD index of banking sector reform. Higher values of the index indicate a more advanced level of banking reform.

Given that foreign-owned banks have a large presence in the banking systems of the CEE countries, we control also for the impact of bank's foreign ownership by including a dummy variable ( $d v$ foreign) that specifies whether the bank is foreign. In addition, since the foreign banks that operate in the CEE region originate from different countries, we consider that the origin of the foreign banks may play a role. Hence, the variable $d v \_$origin is included in the model to control for the impact of the country origin of the foreign banks. According to Haselmann (2006), the activity of the foreign banks is mostly determined by the strategic considerations of the parent banks. In order to take into account the potential impact of time-specific effects, the model includes a complete set of year dummies $\left(d v \_\right.$year $)$. Since the banks included in our sample are from different countries, a complete set of country dummies are included in the model in order to control for country-specific effects $\left(d v \_\right.$country). 


\section{Empirical data and analysis}

At the beginning of transition i.e. the creation of the two-tier banking system, the banking system experienced the creation of oligopolistic market structures in most of transition economies (Papi and Revloltella, 1999). In some countries, the asset portfolio of monobanks were inherited by a single state-owned commercial bank. In other countries the previous specialist banks were transformed into state-owned commercial banks, implying that in general the banking systems were dominated by a small number of large banks (Bonin, 2001). All these banks were state-owned, large in size, segmented in different sectors of the economy (e.g. trade, agriculture and infrastructure) and that the market was still not open to foreign-owned banks. Therefore, it may be considered that they possessed substantial market power and the likelihood of competition taking place between those banks was non-existent or very low. The possibility of these banks competing with each other was limited, particularly due to the lack of commercial banking experience which prohibited them from differentiating their products or introducing new financial products in the market.

The privatization process and the entry of new banks in the market created conditions for the evolution of banking system competition. This especially happened after the foreign banks started to enter the banking markets of the transition economies. This reduced the market power of the domestic banks and introduced modern commercial banking practices. The new banking technologies and products that are usually introduced by foreign banks are expected to induce local banks to engage in more competition (World Bank, 2013). By the end of the first decade of transition, the number of banks in all CEE countries had substantially increased and foreign banks were present in all the countries (Table 2).

However, from 2000, a wave of banking consolidation engulfed the region, thus leading to a decline in the number of banks in most countries. The consolidation trend was driven by the stronger banks being encouraged to take over the weaker banks in order to preserve financial stability, bank shareholders that decided to exit the market, and the mergers of the parent banks of some of the foreign banks operating in the region (Gelos and Roldos, 2004). 
Arben Mustafa, Valentin Toçi $\bullet$ Estimation of the banking sector competition...

Zb. rad. Ekon. fak. Rij. • $2017 \cdot$ vol. $35 \cdot$ no. $2 \cdot 459-485$

Table 2: Number of domestic and foreign banks in CEE, 1999-2009

\begin{tabular}{|c|c|c|c|c|c|c|c|c|c|c|c|}
\hline $\begin{array}{c}\text { Years } \\
\text { Countries }\end{array}$ & 1999 & 2000 & 2001 & 2002 & 2003 & 2004 & 2005 & 2006 & 2007 & 2008 & 2009 \\
\hline Albania & $\begin{array}{r}13 \\
(11) \\
\end{array}$ & $\begin{array}{r}13 \\
(12) \\
\end{array}$ & $\begin{array}{r}13 \\
(12) \\
\end{array}$ & $\begin{array}{r}13 \\
(12) \\
\end{array}$ & $\begin{array}{r}15 \\
(13) \\
\end{array}$ & $\begin{array}{r}16 \\
(14) \\
\end{array}$ & $\begin{array}{r}16 \\
(14)\end{array}$ & $\begin{array}{r}17 \\
(14) \\
\end{array}$ & $\begin{array}{r}17 \\
(15) \\
\end{array}$ & $\begin{array}{r}16 \\
(14)\end{array}$ & $\begin{array}{r}16 \\
(14)\end{array}$ \\
\hline $\begin{array}{l}\text { Bosnia and } \\
\text { Herzegovina }\end{array}$ & $\begin{array}{l}61 \\
(9)\end{array}$ & $\begin{array}{r}56 \\
(14)\end{array}$ & $\begin{array}{r}49 \\
(20) \\
\end{array}$ & $\begin{array}{r}40 \\
(21) \\
\end{array}$ & $\begin{array}{r}37 \\
(19) \\
\end{array}$ & $\begin{array}{r}33 \\
(17) \\
\end{array}$ & $\begin{array}{r}33 \\
(20)\end{array}$ & $\begin{array}{r}32 \\
(22) \\
\end{array}$ & $\begin{array}{r}32 \\
(21) \\
\end{array}$ & $\begin{array}{r}30 \\
(21)\end{array}$ & $\begin{array}{r}30 \\
(21)\end{array}$ \\
\hline Bulgaria & $\begin{array}{r}34 \\
(22) \\
\end{array}$ & $\begin{array}{r}35 \\
(25) \\
\end{array}$ & $\begin{array}{r}35 \\
(26) \\
\end{array}$ & $\begin{array}{r}34 \\
(26) \\
\end{array}$ & $\begin{array}{r}35 \\
(25) \\
\end{array}$ & $\begin{array}{r}35 \\
(24) \\
\end{array}$ & $\begin{array}{r}34 \\
(23) \\
\end{array}$ & $\begin{array}{r}32 \\
(23) \\
\end{array}$ & $\begin{array}{r}29 \\
(21) \\
\end{array}$ & $\begin{array}{r}30 \\
(22) \\
\end{array}$ & $\begin{array}{r}30 \\
(22) \\
\end{array}$ \\
\hline Croatia & $\begin{array}{r}53 \\
(13) \\
\end{array}$ & $\begin{array}{r}43 \\
(21)\end{array}$ & $\begin{array}{r}43 \\
(24) \\
\end{array}$ & $\begin{array}{r}46 \\
(23) \\
\end{array}$ & $\begin{array}{r}41 \\
(19) \\
\end{array}$ & $\begin{array}{r}37 \\
(15) \\
\end{array}$ & $\begin{array}{r}34 \\
(13)\end{array}$ & $\begin{array}{r}33 \\
(15) \\
\end{array}$ & $\begin{array}{r}33 \\
(16)\end{array}$ & $\begin{array}{r}33 \\
(16)\end{array}$ & $\begin{array}{r}32 \\
(15)\end{array}$ \\
\hline $\begin{array}{l}\text { Czech } \\
\text { Republic }\end{array}$ & $\begin{array}{r}42 \\
(27) \\
\end{array}$ & $\begin{array}{r}40 \\
(26) \\
\end{array}$ & $\begin{array}{r}38 \\
(26) \\
\end{array}$ & $\begin{array}{r}37 \\
(26) \\
\end{array}$ & $\begin{array}{r}35 \\
(26) \\
\end{array}$ & $\begin{array}{r}35 \\
(26) \\
\end{array}$ & $\begin{array}{r}36 \\
(27) \\
\end{array}$ & $\begin{array}{r}37 \\
(28) \\
\end{array}$ & - & & 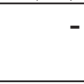 \\
\hline Estonia & $\begin{array}{r}7 \\
(3) \\
\end{array}$ & $\begin{array}{r}7 \\
(4) \\
\end{array}$ & $\begin{array}{r}7 \\
(4) \\
\end{array}$ & $\begin{array}{r}7 \\
\text { (4) } \\
\end{array}$ & $\begin{array}{r}7 \\
(4) \\
\end{array}$ & $\begin{array}{r}9 \\
(6) \\
\end{array}$ & $\begin{array}{r}13 \\
(10) \\
\end{array}$ & $\begin{array}{r}14 \\
(12) \\
\end{array}$ & $\begin{array}{r}15 \\
(13) \\
\end{array}$ & $\begin{array}{r}17 \\
(15) \\
\end{array}$ & $\begin{array}{r}17 \\
(14) \\
\end{array}$ \\
\hline Hungary & $\begin{array}{r}43 \\
(29) \\
\end{array}$ & $\begin{array}{r}42 \\
(33) \\
\end{array}$ & $\begin{array}{r}41 \\
(31) \\
\end{array}$ & $\begin{array}{r}37 \\
(27) \\
\end{array}$ & $\begin{array}{r}36 \\
(29) \\
\end{array}$ & $\begin{array}{r}38 \\
(27) \\
\end{array}$ & $\begin{array}{r}38 \\
(27) \\
\end{array}$ & $\begin{array}{r}40 \\
(28) \\
\end{array}$ & $\begin{array}{r}40 \\
(27) \\
\end{array}$ & $\begin{array}{r}39 \\
(25) \\
\end{array}$ & $\begin{array}{r}38 \\
(23) \\
\end{array}$ \\
\hline Kosovo & $\begin{array}{r}1 \\
(1)\end{array}$ & $\begin{array}{r}2 \\
(2) \\
\end{array}$ & $\begin{array}{r}5 \\
(2) \\
\end{array}$ & $\begin{array}{r}6 \\
(2) \\
\end{array}$ & $\begin{array}{r}6 \\
(2) \\
\end{array}$ & $\begin{array}{r}6 \\
(2) \\
\end{array}$ & $\begin{array}{r}6 \\
(2) \\
\end{array}$ & $\begin{array}{r}6 \\
(2) \\
\end{array}$ & $\begin{array}{r}9 \\
(5) \\
\end{array}$ & $\begin{array}{r}8 \\
(6) \\
\end{array}$ & $\begin{array}{r}8 \\
(6) \\
\end{array}$ \\
\hline Latvia & \begin{tabular}{r|}
23 \\
$(12)$ \\
\end{tabular} & $\begin{array}{r}21 \\
(12)\end{array}$ & $\begin{array}{r}23 \\
(10) \\
\end{array}$ & \begin{tabular}{r|}
23 \\
$(9)$
\end{tabular} & $\begin{array}{r}23 \\
(10) \\
\end{array}$ & $\begin{array}{r}23 \\
(9) \\
\end{array}$ & $\begin{array}{l}23 \\
\text { (9) }\end{array}$ & $\begin{array}{r}24 \\
(12)\end{array}$ & $\begin{array}{r}25 \\
(14)\end{array}$ & $\begin{array}{r}27 \\
\text { (16) }\end{array}$ & $\begin{array}{r}27 \\
(18)\end{array}$ \\
\hline Lithuania & $\begin{array}{r}13 \\
(4)\end{array}$ & $\begin{array}{l}13 \\
\text { (6) }\end{array}$ & $\begin{array}{r}13 \\
(6) \\
\end{array}$ & $\begin{array}{r}14 \\
(7)\end{array}$ & $\begin{array}{r}13 \\
(7)\end{array}$ & $\begin{array}{r}12 \\
(6)\end{array}$ & $\begin{array}{l}12 \\
\text { (6) }\end{array}$ & $\begin{array}{r}11 \\
(6)\end{array}$ & $\begin{array}{l}14 \\
(6)\end{array}$ & $\begin{array}{r}17 \\
(5)\end{array}$ & $\begin{array}{l}17 \\
(5)\end{array}$ \\
\hline Macedonia & $\begin{array}{r}23 \\
(5)\end{array}$ & $\begin{array}{r}22 \\
\text { (7) }\end{array}$ & $\begin{array}{r}21 \\
(8) \\
\end{array}$ & $\begin{array}{r}20 \\
(7)\end{array}$ & $\begin{array}{r}21 \\
(8)\end{array}$ & $\begin{array}{r}21 \\
(8)\end{array}$ & $\begin{array}{r}20 \\
(8)\end{array}$ & $\begin{array}{r}19 \\
(8)\end{array}$ & $\begin{array}{r}18 \\
(11)\end{array}$ & $\begin{array}{r}18 \\
\text { (14) }\end{array}$ & $\begin{array}{r}18 \\
(14)\end{array}$ \\
\hline Montenegro & - & - & - & - & - & $\begin{array}{r}10 \\
\text { (3) } \\
\end{array}$ & $\begin{array}{r}10 \\
\text { (7) } \\
\end{array}$ & $\begin{array}{r}10 \\
(8) \\
\end{array}$ & \begin{tabular}{r|}
11 \\
$(8)$
\end{tabular} & $\begin{array}{r}11 \\
(9) \\
\end{array}$ & $\begin{array}{r}11 \\
(9) \\
\end{array}$ \\
\hline Poland & $\begin{array}{r}77 \\
(39) \\
\end{array}$ & $\begin{array}{r}73 \\
(46) \\
\end{array}$ & $\begin{array}{r}69 \\
(46) \\
\end{array}$ & $\begin{array}{r}59 \\
(45) \\
\end{array}$ & $\begin{array}{r}58 \\
(46) \\
\end{array}$ & $\begin{array}{r}57 \\
(44) \\
\end{array}$ & $\begin{array}{r}61 \\
(50) \\
\end{array}$ & $\begin{array}{r}63 \\
(52) \\
\end{array}$ & $\begin{array}{r}64 \\
(54) \\
\end{array}$ & $\begin{array}{r}70 \\
(60) \\
\end{array}$ & $\begin{array}{r}67 \\
(57) \\
\end{array}$ \\
\hline Romania & $\begin{array}{r}41 \\
(26)\end{array}$ & $\begin{array}{r}41 \\
(29)\end{array}$ & $\begin{array}{r}41 \\
(32)\end{array}$ & $\begin{array}{r}39 \\
(32)\end{array}$ & $\begin{array}{r}38 \\
(29)\end{array}$ & $\begin{array}{r}32 \\
(23)\end{array}$ & $\begin{array}{r}33 \\
(24)\end{array}$ & $\begin{array}{r}31 \\
(26)\end{array}$ & $\begin{array}{r}31 \\
(26)\end{array}$ & $\begin{array}{r}32 \\
(27)\end{array}$ & $\begin{array}{r}31 \\
(25)\end{array}$ \\
\hline Serbia & $\begin{array}{l}75 \\
\text { (3) } \\
\end{array}$ & $\begin{array}{r}81 \\
\text { (3) } \\
\end{array}$ & $\begin{array}{r}54 \\
(8) \\
\end{array}$ & $\begin{array}{r}50 \\
(12) \\
\end{array}$ & $\begin{array}{r}47 \\
(16) \\
\end{array}$ & $\begin{array}{r}43 \\
(11) \\
\end{array}$ & $\begin{array}{r}40 \\
(17) \\
\end{array}$ & $\begin{array}{r}37 \\
(22) \\
\end{array}$ & $\begin{array}{r}35 \\
(21) \\
\end{array}$ & $\begin{array}{r}34 \\
(20) \\
\end{array}$ & - \\
\hline Slovakia & $\begin{array}{r}25 \\
(11)\end{array}$ & $\begin{array}{r}23 \\
(14)\end{array}$ & $\begin{array}{r}21 \\
(13)\end{array}$ & $\begin{array}{r}20 \\
(15)\end{array}$ & $\begin{array}{r}21 \\
(16)\end{array}$ & $\begin{array}{r}21 \\
(16)\end{array}$ & $\begin{array}{r}23 \\
\text { (16) }\end{array}$ & $\begin{array}{r}24 \\
(16)\end{array}$ & $\begin{array}{r}26 \\
(15)\end{array}$ & $\begin{array}{r}26 \\
(16)\end{array}$ & $\begin{array}{r}26 \\
\text { (13) }\end{array}$ \\
\hline Slovenia & $\begin{array}{r}31 \\
(5)\end{array}$ & $\begin{array}{l}28 \\
(6)\end{array}$ & $\begin{array}{r}24 \\
(5)\end{array}$ & $\begin{array}{r}22 \\
(6)\end{array}$ & $\begin{array}{r}22 \\
(6)\end{array}$ & $\begin{array}{r}22 \\
(7)\end{array}$ & $\begin{array}{l}25 \\
\text { (9) }\end{array}$ & $\begin{array}{r}25 \\
(10)\end{array}$ & $\begin{array}{r}27 \\
(11)\end{array}$ & $\begin{array}{r}24 \\
(11)\end{array}$ & $\begin{array}{r}25 \\
\text { (11) }\end{array}$ \\
\hline
\end{tabular}

Note: Numbers in brackets represent foreign banks.

Source: EBRD, Transition Report (various issues 1998-2014); CBK, Annual Report (2013)

The consolidation process created concerns about a potential increase of the degree of market concentration which, according to the Structure-Conduct-Performance (SCP) paradigm, would imply a decline in the banking system competition. This under the assumption that a market with fewer and larger banks is more likely to be characterized by uncompetitive behaviour. However, the degree of market concentration does not appear to have increased after the consolidation process. Market concentration, measured by the Herfindahl-Hirschman Index, appears to 
have followed a gradually declining trend after 2000 (see Table 3). The reason why the consolidation process has not led to increased market concentration may be due to the fact that the taken-over banks, or the banks that exited the market, were mostly small banks. Estonia is the country which recorded an increasing trend of market concentration index, but the increase does not appear to have been related to the decline in the number of banks in this country.

Table 3: Herfindahl-Hirschman Index (deposits market), 1999-2009

\begin{tabular}{|l|r|r|r|r|r|r|r|r|r|r|r|}
\hline \multicolumn{1}{|c|}{ Years } & 1999 & 2000 & 2001 & 2002 & 2003 & 2004 & 2005 & 2006 & 2007 & 2008 & 2009 \\
\hline Albania & 8,859 & 6,978 & 7,672 & 4,696 & 4,019 & 3,618 & 2,957 & 2,631 & 2,342 & 2,311 & 2,358 \\
\hline $\begin{array}{l}\text { Bosnia and } \\
\text { Herzegovina }\end{array}$ & 3,069 & 3,273 & 2,005 & 1,254 & 1,165 & 1,264 & 1,252 & 1,327 & 1,162 & 1,302 & 1,527 \\
\hline Bulgaria & 2,305 & 1,947 & 1,482 & 980 & 968 & 990 & 858 & 865 & 1,077 & 1,084 & 1,210 \\
\hline Croatia & 1,457 & 1,440 & 1,873 & 1,143 & 1,258 & 1,206 & 1,204 & 1,158 & 1,034 & 1,233 & 1,269 \\
\hline Czech Republic & 4,213 & 1,559 & 1,707 & 1,725 & 1,690 & 1,570 & 1,626 & 1,657 & 1,669 & 1,701 & 1,844 \\
\hline Estonia & - & - & 4,926 & 3,773 & 3,743 & 5,092 & 5,483 & 5,948 & 5,791 & 6,500 & 7,751 \\
\hline Hungary & 2,103 & 1,732 & 2,078 & 1,416 & 1,361 & 1,250 & 1,169 & 1,186 & 1,206 & 1,154 & 1,311 \\
\hline Kosovo & - & - & 5,388 & 4,239 & 3,005 & 2,639 & 2,642 & 3,043 & 3,121 & 2,933 & 2,545 \\
\hline Latvia & - & - & - & 1,101 & 1,033 & 998 & 1,178 & 1,083 & 978 & 1,099 & 1,228 \\
\hline Lithuania & - & - & - & 2,625 & 2,582 & 2,338 & 2,050 & 2,109 & 2,115 & 2,031 & 1,950 \\
\hline Macedonia & 3,892 & 3,781 & 3,722 & 2,614 & 2,601 & 2,397 & 2,403 & 2,225 & 2,145 & 2,023 & 2,218 \\
\hline Montenegro & - & - & - & 3,705 & 3,141 & 2,597 & 3,924 & 3,616 & 3,079 & 2,785 & 2,390 \\
\hline Poland & 1,568 & 1,311 & 1,262 & 1,198 & 1,007 & 915 & 885 & 886 & 950 & 781 & 831 \\
\hline Romania & 1,830 & 2,169 & 2,624 & 1,432 & 1,513 & 1,283 & 1,122 & 1,210 & 1,192 & 1,098 & 1,051 \\
\hline Serbia & 5,236 & 5,813 & 2,749 & 1,238 & 1,115 & 832 & 854 & 835 & 793 & 821 & 811 \\
\hline Slovakia & 1,701 & 1,445 & 1,609 & 1,767 & 1,680 & 1,616 & 1,355 & 1,546 & 1,370 & 1,447 & 1,496 \\
\hline Slovenia & 1,964 & 1,990 & - & 2,289 & 1,767 & 1,727 & 1,579 & 1,533 & 1,548 & 1,354 & 1,421 \\
\hline
\end{tabular}

Source: Fitch-IBCA Bankscope database and authors' calculations

Even though market concentration is largely regarded as a measure of competition, this view has increasingly been criticized. For example, the contestability theory maintains that a concentrated market will be characterized by competitive behaviour if there is a credible threat of entry by new entrants (i.e. if there are no or low barriers to entry for potential new entrants). Another argument as to why market concentration may not be an adequate measure of competition is related to the fact that it does not take into account the potential competition from other non-bank financial institutions, such as the micro-finance institutions which, in CEE countries, compete with banks especially in the credit market (Riess et al., 2002). ${ }^{8}$ In addition,

$\overline{8}$ Often data on other financial institutions are lacking and Fitch-IBCA Bankscope database consists of bank data exclusively. Therefore, extending analysis with the impact of other financial institutions in the banking sector falls beyond the scope of the paper. 
banks operating in a country face competition also from banks operating in other countries. For example, in 2005, the cross-border loans to firms in CEE countries averaged at 7.6\% of GDP (Herzberg and Watson, 2007). However, access to crossborder loans is more likely to be available for large multi-national companies, while small and medium sized enterprises are not likely to have easy access to crossborder financing since they are more prone to asymmetric information problems that stem from the lack of credit record and the lack of adequate collateral (Caviglia et al., 2002). Based on this, it may be assumed that banks operating in larger economies, which have a larger pool of foreign companies, are likely to face more competition than banks operating in smaller economies where competition is more likely to be limited within the country boundaries.

The observable factors such as the number of banks, degree of market concentration and the cross-border lending discussed above may to some extent serve as indicators of banking system competition, but these do not necessarily measure the degree of competition. In spite of the fact that foreign banks are considered to have induced competition in the banking systems, it should not be taken for granted that a high level of competition will persist in these markets. According to Kraft (2004), foreign banks are becoming increasingly accommodated to high profits, especially in South-Eastern Europe countries which may make them unwilling to engage in aggressive competition that could eventually undermine their profits.

The bank-specific data in this study are sourced from the Fitch-IBCA Bankscope database, which provides annual data on banks operating all around the globe. Apart from the readily available indicators in this database, we have used the available information to generate additional indicators. Given that the readily available BankScope database provides information only on the current ownership of the bank, we have used the shareholders' history from this database to identify the bank's ownership for the available years as well as the country origin of the foreign bank owners. In this manner, we have constructed the $d v$ foreign variable which takes a value of 1 if the bank is $51 \%$ or more owned by foreigners, and 0 otherwise. Similarly, we have constructed the $d v$ origin variable which takes a value of 1 if the foreign bank comes from an EU-12 country or United States and 0 if the foreign bank's origin is some other country. However, it must be noted that these two variables are characterized by more pronounced missing data which reduces our sample size. 
Table 4: Summary statistics of variables

\begin{tabular}{|l|r|r|r|r|r|}
\hline \multicolumn{1}{|c|}{ Variable } & \multicolumn{1}{c|}{ Obs } & \multicolumn{1}{c|}{ Mean } & \multicolumn{1}{c|}{ Std. Dev. } & \multicolumn{1}{c|}{ Min } & \multicolumn{1}{c|}{ Max } \\
\hline int_inc_real & 2916 & 105167 & 235138 & 115 & 3177846 \\
\hline p_funds & 2906 & 0.039 & 0.036 & 0.000 & 0.816 \\
\hline p_labour & 2495 & 0.018 & 0.015 & 0.001 & 0.220 \\
\hline p_physcapital & 2884 & 2.454 & 5.332 & 0.029 & 94.029 \\
\hline loans_ta & 2904 & 0.550 & 0.203 & 0.000 & 1.396 \\
\hline equity_ta & 2926 & 0.154 & 0.133 & -0.124 & 0.987 \\
\hline prov_loans & 2628 & 0.019 & 0.049 & -0.482 & 0.497 \\
\hline Ta & 2926 & 1732561 & 3849060 & 2981 & 38100000 \\
\hline Rgdpgrowth & 2909 & 3.976 & 4.172 & -17.729 & 13.501 \\
\hline ebrd_bankreform & 2914 & 3.343 & 0.572 & 1.000 & 4.000 \\
\hline dv_foreign & 2155 & 0.638 & 0.481 & 0.000 & 1.000 \\
\hline dv_origin & 2155 & 0.484 & 0.500 & 0.000 & 1.000 \\
\hline
\end{tabular}

Source: Fitch-IBCA Bankscope database and authors' calculations

The data on the real GDP growth rates are obtained from the European Union Commission (AMECO database) and International Monetary Fund. The index on banking reform is obtained from the European Bank for Reconstruction and Development (EBRD) Transition Reports. Summary statistics are presented in Table 4 show the variability of the data included in the analysis. The table also shows that the number of observations for the dummy variable $d v$ foreign and $d v_{-}$ origin is smaller than for other variables due to availability of the data on banks', ownership in the Fitch-IBCA Bankscope database.

\section{Estimation results and discussion}

This section presents the estimation results from the application of the P-R model to measure banking sector competition in the CEE countries during the period 19992009. Table 5 presents the results derived from five different model specifications, which are explained in the notes below the table. The results of the main model specification are presented in the first column of the table.

The estimation results suggest that the behaviour of banks operating in the CEE countries is consistent with monopoly behaviour given that the sum of the coefficients of input prices ( $\log p \_$funds, logp_labour, logp_physcapital) has produced a negative $\mathrm{H}$-statistic equal to -0.064 (Table 5, Specification 1). The linear combination test suggests that the joint impact of the input prices on the interest income (i.e. the dependent variable) is statistically insignificant, implying that the H-statistic is not significantly different from zero. This provides further evidence in support of the monopoly behaviour, given that also an $\mathrm{H}=0$ is considered to imply monopoly 
behaviour (Table 6). The negative value of the H-statistic suggests that the increase of input prices leads to a reduction of banks' interest revenues. Under a monopoly structure, an increase of input prices will increase firms' marginal costs which will lead to an increase of output prices and to a reduction of the level of output. The reduction of the output level will subsequently lead to a decline of banks' revenues. It should also be acknowledged that a negative $\mathrm{H}$-statistic might also be consistent with oligopoly. In this context, the negative value of the $\mathrm{H}$-statistic might still signal that the banking sectors of the CEE countries exert a high degree of market power, but the magnitude of the market power would be lower than in the case of monopoly. Taking into consideration the number of banks operating in the CEE countries, the finding that the banking systems of these countries have been characterized by monopoly behaviour may be considered as unexpected. However, the persisting low degree of financial intermediation, the higher interest rate spreads compared to the Euro Area and the slow progress in the development of competition policy, may represent important illustrative facts that banks that have operated in the CEE during the period 1999-2009 have behaved like monopolies.

As discussed earlier, the studies that have applied the P-R model have not reached a conclusion on whether the interest income or the total income is more appropriate measure to be used as dependent variable. Therefore, to test for the robustness of the results, we have run an additional regression using total income as the dependent variable. The results seem to be consistent, producing an $\mathrm{H}$-statistic of -0.14. In absolute size is larger than the H-statistic obtained in the first specification but still negative, suggesting that CEE banking sectors are characterized by monopoly behaviour (Table 5, Specification 2). Given that both specifications produce a negative $\mathrm{H}$-statistic, it may be considered that the choice between the interest income and total income for the dependent variable is not highly relevant for the estimation of the competitive behaviour of the banks.

The non-EU and EU CEE countries differ in many aspects of banking sector structure and overall operating environment. Thus, we have also tested whether the degree of banking sector competition in the non-EU members of the CEE region was different from the EU members of this region. We have conducted this test by interacting each of the input prices variables (i.e. the components of the H-statistic) with the dummy variable $d v$ noneu, which takes value of 1 if the country is not an EU member (Table 5, specification 3). ${ }^{9}$ According to Brambor et al. (2006), the coefficient of a constitutive component of the interaction term can be interpreted alone only assuming that the other constitutive component of the interaction term equals zero. In our

\footnotetext{
9 The inclusion of the interaction term is done in line with Brambor et al. (2006) who suggest that in the case of multiplicative interaction models, the regression should include all the constitutive terms of the interaction term and the interaction term itself. These authors suggest that the coefficients of the constitutive terms should not be interpreted as average effects. The coefficient of one component term can be interpreted only assuming that the other component of the interaction term equals zero.
} 
case, the coeficients of the primary variables $p_{\_}$funds, $p_{-}$labour and $p_{\text {p physcapital }}$ reflect the impact of input prices on banks' revenues when the other component of the interaction term (i.e. $d v \_n o n e u$ ) equals zero. The coefficients of the interaction terms in our regression (logpfunds_dvnoneu, logplabour_dvnoneu and logpphyscapital_ $d v$ noneu) suggest that when $\bar{d} v_{-}$noneu equals 1 , i.e. when the country is a non-EU member, the input prices have a statistically significant additional impact on bank's revenues compared to the situation when the country is an EU member.

Table 5: Estimation results of the H-statistic for the CEE countries

\begin{tabular}{|c|c|c|c|c|c|}
\hline Variables & (1) & (2) & (3) & (4) & (5) \\
\hline \multirow[t]{2}{*}{ Laglogint_inc_real } & $0.856^{* * *}$ & & $0.748^{* * *}$ & & $0.171^{* * *}$ \\
\hline & $(0.071)$ & & $(0.062)$ & & $(0.043)$ \\
\hline \multirow[t]{2}{*}{ logp_funds } & $0.129^{* * * *}$ & $0.156^{* * *}$ & $0.220^{* * * *}$ & $0.376^{* * *}$ & $0.342^{* * *}$ \\
\hline & $(0.042)$ & $(0.050)$ & $(0.050)$ & $(0.031)$ & $(0.034)$ \\
\hline \multirow[t]{2}{*}{ logp_labour } & $-0.141^{* * *}$ & $-0.185^{* *}$ & $-0.173^{* * *}$ & $0.155^{* * *}$ & $0.154^{* * *}$ \\
\hline & $(0.046)$ & $(0.091)$ & $(0.058)$ & $(0.019)$ & $(0.022)$ \\
\hline \multirow[t]{2}{*}{ logp_physcapital } & -0.051 & -0.111 & $-0.134^{* * *}$ & $0.025^{* *}$ & $0.024^{* *}$ \\
\hline & $(0.035)$ & $(0.082)$ & $(0.045)$ & $(0.010)$ & $(0.010)$ \\
\hline \multirow[t]{2}{*}{ loans_ta } & 0.063 & 0.072 & 0.061 & $0.193^{* *}$ & $0.379^{* * *}$ \\
\hline & $(0.077)$ & $(0.123)$ & $(0.089)$ & $(0.097)$ & $(0.100)$ \\
\hline \multirow[t]{2}{*}{ equity_ta } & $-0.853^{* *}$ & $-1.559^{*}$ & $-1.287^{* * * *}$ & $0.541^{* * *}$ & $0.582^{* *}$ \\
\hline & $(0.346)$ & $(0.855)$ & $(0.351)$ & $(0.199)$ & $(0.271)$ \\
\hline \multirow[t]{2}{*}{ prov_loans } & -0.168 & $0.916^{*}$ & -0.215 & -0.179 & -0.645 \\
\hline & $(0.297)$ & $(0.539)$ & $(0.323)$ & $(0.394)$ & $(0.516)$ \\
\hline \multirow[t]{2}{*}{ Rgdpgrowth } & $0.022^{* * *}$ & $0.020^{* * * *}$ & $0.019^{* * * *}$ & $0.005^{* * *}$ & $0.008^{* * *}$ \\
\hline & $(0.003)$ & $(0.004)$ & $(0.003)$ & $(0.002)$ & $(0.002)$ \\
\hline \multirow[t]{2}{*}{ ebrd_bankref } & $-0.161^{* * * *}$ & $-0.186^{* *}$ & -0.102 & 0.027 & -0.059 \\
\hline & $(0.062)$ & $(0.080)$ & $(0.067)$ & $(0.028)$ & $(0.036)$ \\
\hline \multirow[t]{2}{*}{$\mathrm{dv}$ _foreign } & 0.066 & 0.047 & 0.070 & -0.030 & $-0.049^{*}$ \\
\hline & $(0.042)$ & $(0.077)$ & $(0.051)$ & $(0.023)$ & $(0.025)$ \\
\hline \multirow[t]{2}{*}{$\mathrm{dv}$ _origin } & 0.057 & 0.122 & $0.098^{*}$ & 0.017 & -0.006 \\
\hline & $(0.060)$ & $(0.112)$ & $(0.054)$ & $(0.020)$ & $(0.022)$ \\
\hline \multirow[t]{2}{*}{ logpfunds_dvnoneu } & & & $-0.150^{* * *}$ & & \\
\hline & & & $(0.067)$ & & \\
\hline \multirow[t]{2}{*}{ logplabour_dvnoneu } & & & $-0.176^{* *}$ & & \\
\hline & & & $(0.087)$ & & \\
\hline \multirow[t]{2}{*}{ logpphyscapital_dvnoneu } & & & $0.112^{* *}$ & & \\
\hline & & & $(0.055)$ & & \\
\hline \multirow[t]{2}{*}{ dv_noneu } & & & $-1.700^{* * * *}$ & & \\
\hline & & & $(0.497)$ & & \\
\hline \multirow{2}{*}{ Laglogtot_inc_real } & & $0.709^{* * *}$ & & & \\
\hline & & $(0.173)$ & & & \\
\hline \multirow[t]{2}{*}{ Laglogintinc_ta } & & & & $0.280^{* * * *}$ & \\
\hline & & & & $(0.053)$ & \\
\hline
\end{tabular}


Arben Mustafa, Valentin Toçi $\bullet$ Estimation of the banking sector competition...

\begin{tabular}{|l|r|r|r|r|r|}
\hline \multicolumn{1}{|c|}{ Variables } & $(1)$ & $(2)$ & \multicolumn{1}{c|}{$(3)$} & \multicolumn{1}{c|}{$(4)$} & \multicolumn{1}{c|}{$(5)$} \\
\hline Logta & & & & & \multicolumn{1}{c|}{$0.850^{* * *}$} \\
\hline & & & & & $(0.046)$ \\
\hline & & & & & Yes \\
\hline dv_year & Yes & Yes & Yes & Yes & Yes \\
\hline dv_country & Yes & Yes & Yes & Yes & Yes \\
\hline & & & & & -0.143 \\
\hline Constant & $1.747^{* * *}$ & $3.286^{* *}$ & $3.222^{* * *}$ & $-0.807^{* * *}$ \\
\hline & $(0.654)$ & $(1.477)$ & $(0.704)$ & $(0.173)$ & $(0.254)$ \\
\hline & & & & & \\
\hline Observations & 1,610 & 1,607 & 1,610 & 1,610 & 1,610 \\
\hline Number of banks & 299 & 298 & 299 & 299 & 299 \\
\hline
\end{tabular}

Note a): Standard errors in parentheses. $* * * \mathrm{p}<0.01, * * \mathrm{p}<0.05, * \mathrm{p}<0.1$.

Note b): Specification 1 uses the real interest income as dependent variable; Specification 2 uses the real total income as dependent variable; Specification 3 uses real interest income as dependent variable, but includes the interactions of input price variables with the dummy variable for non-EU countries; Specification 4 uses the interest income to total assets ratio as dependent variable; Specification 5 uses the real interest income as dependent variable, but includes the total assets variable among the explanatory variables.

Source: Authors' calculations

Summing up, the coefficient of each interaction term (logpfunds_dvnoneu, logplabour_dvnoneu and logpphyscapital_dvnoneu) with the coefficient of its respective constitutive term ( $p_{\_}$funds, $p_{-}$labour and $p_{\text {_ }}$ physcapital), the H-statistic for the non-EU members of our sample is obtained. This represents the impact of input prices on bank's revenues when the country is an EU member plus the additional impact when the country is not an EU member. The sum of these coefficients is presented in Table 6 (specification 3) and shows an H-statistic of -0.30 for the non-EU countries. The fact the H-statistic for non-EU countries is smaller than the H-statistic for the whole sample, suggests that the banking sectors of non-EU countries are characterized by a lower degree of competition compared to the banking sectors of the EU countries.

The non-EU countries of the CEE region have been characterized by a lower degree of financial intermediation, higher interest rate spreads, and lower development of competition policy, compared to the EU members of the region, which might serve as indicators of a lower degree of banking sector competition in these countries. Banks operating in the non-EU countries of the CEE are also likely to face less competition from cross-border lending, given the smaller number of large foreign corporations operating in these countries. In addition, the persistently high profitability ratios recorded by the banking sectors of these countries might have well accommodated banks in the existing positions as to not induce a more aggressive competitive behaviour which could eventually undermine their profits. 
The coefficient on the lagged dependent variable (Laglogintinc_real) is positive and highly significant, showing a high level of persistence of the bank interest revenues over the periods (Table 5). This implies that bank revenues in the current year are largely consistent with the bank revenues in the previous year. The statistically significant coefficient of the lagged dependent variable confirms the dynamic nature of our model and may serve as evidence in support to Goddard and Wilson (2009) who suggest that the P-R model should be estimated using dynamic models rather than static models as used by the majority of studies applying this method.

Regarding other control variables, the degree of risk-aversion, measured by the equity to total assets ratio (equity_ta) has a negative and statistically significant coefficient, showing that more conservative banks tend to generate less interest income. However, this could be interpreted as more capitalized banks have more leverage to be more aggressive in the market via lower interest rates. The structure of the assets (loans_ta) and the quality of the loan portfolio (prov_loans) have statistically insignificant coefficients. Also, bank's ownership $\left(d v_{-}\right.$foreign) and country-of-origin ( $d v \_$origin) both statistically insignificant coefficients. Regarding country-level variables, the real GDP growth rate (rgdpgrowth) has a positive and statistically significant coefficient, while the banking reform index (ebrd_bankref) is significantly negative. This implies that overall operating environment of banks leads to more efficient banking markets via lower interest rate margins.

Table 6: Joint impact of the input prices on the dependent variable

\begin{tabular}{|l|r|r|c|r|r|r|}
\hline Model specification & Coefficient & Std. error & \multicolumn{1}{c|}{$\mathrm{Z}$} & \multicolumn{1}{c|}{$\mathrm{P}>|\mathrm{z}|$} & \multicolumn{2}{|c|}{ [95\% Conf. Interval] } \\
\hline Specification 1 & -0.064 & 0.066 & -0.960 & 0.337 & -0.194 & 0.066 \\
\hline Specification 2 & -0.140 & 0.138 & -1.020 & 0.309 & -0.410 & 0.130 \\
\hline Specification 3 & -0.300 & 0.115 & -2.610 & 0.009 & -0.526 & -0.075 \\
\hline Specification 4 & 0.556 & 0.043 & 13.070 & 0.000 & 0.473 & 0.640 \\
\hline Specification 5 & 0.519 & 0.051 & 10.220 & 0.000 & 0.419 & 0.618 \\
\hline
\end{tabular}

Note a): The joint impact of the input prices on the dependent variable is calculated using the linear combinations command (lincom) in STATA. The coefficient column in this table represents the sum of the coefficients on $\log p_{-}$funds, $\log p_{-}$labour and logp_physcapital (for Specification 3: logpfunds_dvnoneu+logp_funds, logplabour_dvnoneu+logp labour, logpphyscapital_dvnoneu+logp_physcapital) which produces the H-statistic.

Note b): Specification 1 corresponds to the model with the interest income as dependent variable; Specification 2 corresponds to the model with the total income as dependent variable; Specification 3 uses real interest income as dependent variable, but includes the interactions of input price variables with the dummy variable for non-EU countries; Specification 4 corresponds to the model with the interest income to total assets ratio as dependent variable; Specification 5 corresponds to the model with the interest income as dependent variable, but which includes also total assets among the explanatory variables.

Source: Authors' calculations 
The main finding of our analysis is that the competitive behaviour of banks operating in the CEE countries complies with monopoly behaviour. This is not consistent with the findings of the most other studies that have applied the P-R model to investigate banking sector competition for the CEE countries, as well as with studies that have applied this approach to other regions which have mostly found monopolistic competition (Mamatzakis et al., 2005; Yildirim and Philippatos, 2007; Claessens and Laeven, 2004). However, this difference might be attributed to the model specification, given that we have made an improvement to the model specification by taking into account the suggestion of Bikker et al. $(2012 ; 2007)$ not to scale the dependent variable (i.e. interest income or total income) to total assets, but also not to control for total assets among the explanatory variables. In order to test the hypothesis of Bikker et al. (2012), that the inclusion of total assets as an explanatory variable leads to a higher and always positive $\mathrm{H}$-statistic, we have estimated equation 2 by scaling the dependent variable to total assets (Table 5, Specification 4). As expected, the H-statistic turns from negative in the previous specification to positive with a coefficient of 0.556 which would suggest that the behaviour of banks operating in the CEE countries is consistent with monopolistic competition (Table 6, Specification 5). ${ }^{10}$ Similarly, we estimate equation 2 with total assets (logta) among the explanatory variables. The results are similar with an $\mathrm{H}$-statistic of 0.519 (Table 5, Specification 5). These results may serve as important evidence in support of the hypothesis of Bikker et al. $(2012$; 2007) on the use of total assets to scale the dependent variable or to control for total assets in a PanzarRosse model, suggesting that the application of the Panzar-Rosse model requires to maintain the reduced-form revenue equation. Otherwise, the transformation of the reduced-form revenue equation into a price equation will lead to biased results.

\section{Conclusions}

The estimation results have produced a negative $\mathrm{H}$-statistic, which implies that the behaviour of banks operating in the CEE countries is consistent with monopoly behaviour - the first hypothesis of the paper. Taking into consideration the number of banks operating in the banking markets of CEE countries, this finding might be considered as unexpected. However, the persisting low degree of financial intermediation, the higher interest rate spreads compared to the Euro Area and the slow progress in the development of competition policies may represent important illustrative facts suggesting that the banks that have operated in the CEE during

\footnotetext{
${ }^{10}$ Given that the scaling of the dependent variable to total assets and the inclusion of total assets as an explanatory variable (Specifications 4 and 5) transform the reduced-form revenue equation into a price equation (i.e. the dependent variable becomes the ex post interest rate), in these specifications the control variables equity_ta, loans_ta, prov_loans, and logta are treated as endogenous based on the predicted relationship between these variables and the interest rate.
} 
the period 1999-2009 have behaved like monopolies. Nevertheless, it should be acknowledged that a negative $\mathrm{H}$-statistic might be consistent also with oligopoly market structure, implying that our estimate of the H-statistic would still signal the presence of a high degree of market power, but which is more moderate compared to the monopoly.

Within the CEE sample of countries, market power resulted to be higher among the banks operating in the non-EU countries of the CEE region compared to the EU countries of this region - the second hypothesis of the paper. These countries have been characterized by lower degree of financial intermediation, higher interest rate spreads, and lower development of competition policy, compared to the EU members of the CEE region. The banks operating in the non-EU countries of the $\mathrm{CEE}$ are also likely to face less competition from cross-border lending. In addition, the persistently high profitability ratios recorded by the banking sectors of these countries might have well accommodated banks in their existing positions as to not induce a more aggressive competitive behaviour, which could eventually undermine their profits. Therefore, the results suggest that despite the opening to the entry of foreign banks, the banking sectors of the CEE region still remain uncompetitive and, hence, there may be ample room for a further enhancement of the financial intermediation efficiency in the countries through the increase of competition.

This paper has addressed an important methodological problem related to the Panzar-Rosse approach. Our results provide support for the hypothesis of Bikker et al. $(2012$; 2007) - the third hypothesis of the paper - who suggest that scaling the dependent variable or controlling for total assets in the regression transforms the revenue equation into a price equation and, hence, produces an upwards biased $\mathrm{H}$-statistic that always rejects monopoly. This may lead to misleading results with implications in policy-making. Therefore, the results produced from this study may be considered to be more reliable compared to other studies that have used this method to estimate the banking sector competition. The other specification issue was related to the choice between interest income and total income to be used as dependent variable. The results have generally been consistent using either of these two variables, suggesting that the choice between the interest income and the total income for the dependent variable is not highly important for the measurement of banking sector competition using the Panzar-Rosse approach.

Having into consideration the importance of banking sector competition for the financial intermediation efficiency and the main finding of this paper that the degree of competition in these countries is low, the main policy implication of this paper is that the authorities in the CEE countries should take additional measures to induce the banking sector competition. Central banks could encourage entry (making the market more contestable), but at the same time should take care of the quality of new entrants. The general 'enabling' environment that attracts entry of sound banks, in conjunction with strict regulation and supervision is important 
policy implication. Also competition authorities may be more active in identifying possible collusive behavior of banking sectors in the region.

Regulatory institutions can also focus in other measures that reduce the barriers to competition. For example, banks should make the 'terms and conditions' of individual bank products easily understandable for the clients so that they can make comparisons between the products offered by different banks. In addition, the authorities should make sure that the 'switching costs' between banks do not serve as a source of market power for the banks.

We consider that this paper offers a good ground for the analysis of the competitive conditions in the banking sectors of the CEE countries, but we strongly recommend further research to be undertaken in order to further strengthen the inferences on the competitive behaviour of banks in this region. In this paper the impact of the global financial crisis and post-crisis period was not under investigation. Global financial crisis and the post-crisis period represents turbulent and structural changes in the banking sectors worldwide, including the CEE countries. This may have led to short-run 'equilibrium solutions' in the light of regulatory changes, overall institutional responses and takeovers, mergers and acquisitions in the banking sectors. This, in concert with rapid changes in technology and digitalization in banking, requires rethinking methodologies of measuring competition, including variables that construct models, i.e. the input prices variables in the Panzar-Rosse model. Therefore, the impact of the global financial crisis and post-crisis structural changes in the banking sector competition pose important agenda for future research. In addition, the Panzar-Rosse approach measures the average competitive behaviour of the banks in the totality of their operations. However, given that banks organize their operations based on different business segments, it would be an interesting exercise to measure the competitive behaviour of banks across those different business segments. Boone indicator may represent a suitable method for this purpose.

\section{References}

Apergis, N. (2015) "Competition in the Banking Sector: New evidence from a Panel of Emerging Market Economies and the Financial Crisis", Emerging Markets Review, Vol. 25, pp. 154-162, doi: 10.1016/j.ememar.2015.08.001.

Arellano, M., Bond, S. (1991) "Some Tests of Specification for Panel Data: Monte Carlo Evidence and an Application to Employment Equations", Review of Economic Studies, Vol. 58, No. 2, pp. 277-297, doi: 10.2307/2297968.

Arellano, M., Bover, O. (1995) "Another Look at the Instrumental Variable Estimation of Error-Components Models", Journal of Econometrics, Vol. 68, No. 1, pp. 29-52, doi: 10.1016/0304-4076(94)01642-D. 
Bain, J. (1951) "Relation of Profit Rate to Industry Concentration: American Manufacturing, 1936-1940", Quarterly Journal of Economics, Vol. 65, No. 3, pp. 293-324, doi: 10.2307/1882217.

Bandt, O., Davis, P. (2000) "Competition, Contestability and Market Structure in European Banking Sectors on the Eve of EMU", Journal of Banking and Finance, Vol. 24, No. 6, pp. 1045-1066, doi: 10.1016/S0378-4266(99)00117-X.

Baumol, W. (1983) "Contestable Markets: An Uprising in the Theory of Industry Structure", The American Economic Review, Vol. 73, No. 3, pp. 491-496.

Bikker, J., Groenveld, J. (1998) Competition and Concentration in the EU Banking Industry, De Nederlandsche Bank, Research Series Supervision no. 8. Amsterdam: DNB.

Bikker, J., Haaf, K. (2002) "Competition, Concentration and their Relationship: An Empirical Analysis of the Banking Industry", Journal of Banking and Finance, Vol. 26, No. 11, pp. 2191-2214, doi: 10.1016/S0378-4266(02)00205-4.

Bikker, J., Spierdijk, L., Finnie, P. (2007) Misspecification of the Panzar-Rosse Model: Assessing Competition in the Banking Industry, De Nederlandsche Bank working paper series no. 114, Amsterdam: DNB.

Bikker, J., Shaffer, S., Spierdijk, L. (2012) “Assessing Competition with the PanzarRosse Model: The Role of Scale, Costs, and Equilibrium", Review of Economics and Statistics, Vol. 94, No. 4, pp. 1025-1044, doi: 10.1162/REST_a_00210.

Blundell, R., Bond, S. (1998) "Initial Conditions and Moment Restrictions in Dynamic Panel Data Models", Journal of Econometrics, Vol. 87, No. 1, pp. 115-143, doi: 10.1016/S0304-4076(98)00009-8.

Bonin, J., Mizsei, K., Szekely, I., Wachtel, P. (1999) Banking in Transition Economies. Developing Market Oriented Banking Sectors in Eastern Europe, Cheltenham, UK: Edward Elgar Publishing.

Bonin, J. (2001) Financial Intermediation in Southeast Europe: Banking on the Balkans, The WIIW Balkan Observatory working paper series no. 006, Vienna: WIIW.

Boone, J. (2008) "A New Way to Measure Competition", Economic Journal, Vol. 118, No. 531, pp. 1245-1261, doi: 10.1111/j.1468-0297.2008.02168.x

Brambor, T., Clark, W., Golder, M. (2006) "Understanding Interaction Models: Improving Empirical Analyses", Political Analysis, Vol. 14, No. 1, pp. 63-82, doi: 10.1093/pan/mpi014.

Casman, A., Carvallo, O. (2014) "Financial Stability, Competition and Efficiency in Latin American and Caribbean Banking", Journal of Applied Economics, Vol. 17, No. 2, pp. 301-324, doi: 10.1016/S1514-0326(14)60014-3.

Casu, B., Girardone, C. (2006) "Bank Competition, Concentration and Efficiency in the Single European Market”, The Manchester School, Vol. 74, No. 4, pp. 441468, doi: 10.1111/j.1467-9957.2006.00503.x. 
Caviglia, G., Krause, G., Thimann, C. (2002) "Key Features of the Financial Sectors in EU Accession Countries". In Financial Sectors in EU Accession Countries, Frankfurt: ECB.

Central Bank of the Republic of Kosovo (2013), Annual Report, Prishtina: CBK.

Claessens, S., Laeven, L. (2004) "What Drives Bank Competition? Some International Evidence", Journal of Money, Credit, and Banking, Vol. 36, No. 3, pp. 563-583, doi: $10.1353 / \mathrm{mcb} .2004 .0044$.

De Rozas, L. (2007) "Testing for Competition in the Spanish Banking Industry: The Panzar-Rosse Approach Revisited", Banco de España research papers no. 0726, Madrid: Banco de España, doi: 10.2139/ssrn.1005116.

Delis, M. (2010) "Competitive Conditions in the Central and Eastern European Banking Systems, Omega, Vol. 38, No. 5, pp. 268-274, doi: 10.1016/j. omega.2008.09.002.

European Bank for Reconstruction and Development (various issues 1998-2014), Transition Report, London: EBRD.

Gelos, R., Roldós, J. (2004), "Consolidation and Market Structure in Emerging Market Banking Systems", Emerging Markets Review, Vol. 5, No. 1, pp. 39-59, doi: 10.1016/j.ememar.2003.12.002.

Goddard, J., Wilson, J. (2009) "Competition in Banking: A Disequilibrium Approach", Journal of Banking and Finance, Vol. 33, No. 12, pp. 2282-2292, doi: 10.1016/j.jbankfin.2009.06.003.

Haselmann, R. (2006) "Strategies of Foreign Banks in Transition Economies", Emerging Markets Review, Vol. 7, No. 4, pp. 283-299, doi: 10.1016/j. ememar.2006.09.002.

Hahn, F. (2008) "Testing for Profitability and Contestability in Banking: Evidence from Austria", International Review of Applied Economics, Vol. 22, No. 5, pp. 639-653, doi: 10.1080/02692170802287722.

Herzberg, V., Watson, M. (2007) Growth, Risks and Governance: The Role of the Financial Sector in Southeastern Europe, European Economy occasional papers no.29. Brussels: European Commission.

Kraft, E. (2004) "Banking Reform in Southeast Europe: Accomplishments and Challenges", presented at Oesterreichische Nationalbank, Conference on European Economic Integration, November 28-30, 2004, Vienna.

Mamatzakis, E., Staikourasa, C., Koutsomanoli-Fillipaki, N. (2005) "Competition and Concentration in the Banking Sector of the South Eastern European Region", Emerging Markets Review, Vol. 6, No. 2, pp. 192-209, doi: 10.1016/j. ememar.2005.03.003.

Memić, D. (2015) "Banking Competition and Efficiency: Empirical Analysis on the Bosnia and Herzegovina Using Panzar-Rosse Model", International Journal of the Society for Advancing Innovation and Research in Economy, Vol. 6, No. 1, pp. 72-92, doi: 10.1515/bsrj-2015-0005. 
Mustafa, A. (2014) Banking sector competition and its impact on banks' risk-taking and interest margins in the Central and East European countries, $\mathrm{PhD}$ thesis, Staffordshire University, United Kingdom.

Nathan, A., Neave, E. (1989) "Competition and Contestability in Canada's Financial System: Empirical Results", The Canadian Journal of Economics, Vol. 22, No. 3, pp. 576-594, doi: 10.2307/135541.

Papi, L., Revoltella, D. (1999) Foreign Direct Investment in the Banking Sector: A Transitional Economy Perspective, Centro Studi Luca D'Agliano Development Studies working paper series no. 133. Milano: University of Milano.

Perrakis, S., Baumol, W., Panzar, J., Willig, R. (1982) "Contestable Markets and the Theory of Industry Structure", The Canadian Journal of Economics, Vol. 15, No. 4, pp. 774-780, doi: 10.2307/134928.

Riess, A., Wagenvoort, R., Zajc, P. (2002) "Practice Makes Perfect: A Review of Banking in Central and Eastern Europe", EIB Papers, Vol. 7, No.1, pp. 31-53, doi: http:/hdl.handle.net/10419/44820.

Roodman, D. (2005) "XTABOND2: Stata Module to Extend xtabond Dynamic Panel Data Estimator", Washington: Center for Global Development.

Roodman, D. (2009) "A Note on the Theme of Too Many Instruments", Oxford Bulletin of Economics and Statistics, Vol. 71, No. 1, pp. 135-158, doi: 10.1111/j.1468-0084.2008.00542.x.

Sarafidis, V., Yamagata, T., Robertson, R. (2009) "A Test of Cross-Section Dependence for a Linear Dynamic Panel Model with Regressors", Journal of Econometrics, Vol. 148, No. 2, pp. 149-161, doi: 10.1016/j.jeconom.2008.10.006.

Sealey, C., Lindley, J. (1977) "Inputs, Outputs, and a Theory of Production and Cost at Depository Financial Institutions", Journal of Finance, Vol. 32, No. 4, pp. 1251-1266, doi: 10.2307/2326527.

Staikouras, C., Koutsomanoli-Fillipaki, A. (2006) "Competition and Concentration in the New European Banking Landscape", European Financial Management, Vol. 12, No. 3, pp. 443-482, doi: 10.1111/j.1354-7798.2006.00327.x.

Tang, H., Zoli, E., Klytchnikova, I. (2000) Banking Crises in Transition Economies: Fiscal Costs and Related Issues, World Bank Policy Research working paper series no. 2484. Washington, D.C: The World Bank.

World Bank (2013) "The Role of the State in Promoting Bank Competition". In Global Financial Development Report 2013, Washington, D.C: The World Bank, doi: 10.1596/9780821395035_CH03.World Bank (2016) World Development Indicators. Available from: http://databank.worldbank.org/data/reports.aspx? source $=$ world-development-indicators [Accessed $15^{\text {th }}$ December 2016].

Yildirim, S., Philipatos, G. (2007) "Competition and Contestability in Central and Eastern European Banking Markets", Managerial Finance, Vol. 33, No. 3, pp. 195-209, doi: 10.1108/03074350710718275. 


\title{
Procjena konkurentnosti bankarskog sektora u zemljama srednje i istočne Europe: Panzar-Rosseov pristup ${ }^{1}$
}

\author{
Arben Mustafa ${ }^{2}$, Valentin Toçi $i^{3}$
}

\begin{abstract}
Sažetak
Konkurentnost bankarskog sektora u svjetlu tranzicijskog procesa u zemljama Srednje i Istočne Europe (SIE) od posebnog je interesa istraživačima i kreatorima politike, osobito nakon ulaska stranih banaka i koncentriranih tržišta. U ovom se radu koristi Panzar-Rosseov pristup za procjenu stupnja konkurentnosti bankarskog sektora u Srednjoj i Istočnoj Europi. Primjenom opće metode momenata na panel analizu 300 banaka za razdoblje 1999-2009, empirijski dokazi upućuju na to da banke koje djeluju u srednjoj i istočnoj Europi djeluju u uvjetima monopolskog tržišta. S metodološkog stajališta, rezultati upućuju na to da u Panzar-Rosseovom pristupu, upotreba jednadžbe cijena ili kontrolne varijable imovine stvara unaprijed pristranu i pogrešnu procjenu H-statističkih podataka. Stoga se služimo reduciranim oblikom jednadžbe prihoda pri procjeni PanzarRosseovog modela. Nadalje, rezultati ukazuju da u zemljama Srednje i Istočne Europe koje nisu članice EU-a, banke imaju jaču tržišnu snagu u usporedbi s bankama koje djeluju u zemljama članicama EU-a u ovoj regiji. Nositelji politike trebali bi poboljšati konkurentne uvjete $i$ opće "omogućavanje" okružja za bankarske sektore, osobito u zemljama Srednje i Istočne Europe koje nisu članice EU-a, pritom vodeći računa o konkurentnosti i stabilnosti.
\end{abstract}

Ključne riječi: banke, konkurencija, Panzar-Rosseov pristup, Srednja i Istočna Europa

JEL klasifikacija: $G 21, D 4, P 2$

1 Zahvala: Zahvaljujemo Geoffreyu Pughu, Iraj Hashi, anonimnim recenzentima kao i sudionicima na 1. međunarodnoj konferenciji "Pametne ideje i novi koncept ekonomske regeneracije u Europi" - SINCERE, Dubrovnik, Hrvatska 28. rujna - 1. listopada 2016. godine za korisne komentare. Za stavove u ovom radu isključivo su odgovorni autori te se ne bi smjelo tumačiti da odražavaju stajališta institucija s kojima su autori povezani.

2 Docent, Sveučilište u Gjilanu "Kadri Zeka”, Ekonomski fakultet, 60000 Gjilan, Republika Kosovo i CERGE-EI Teaching Career Integration Fellow. Znanstveni interes: makroekonomija, financijska ekonomija, bankarstvo.Tel.: +377 44376 555.E-mail: arben.mustafa@uni-gjilan.net.

3 Izvanredni profesor, Sveučilište u Prištini, "Hasan Prishtina", Ekonomski fakultet, 10000 Priština, Republika Kosovo. Znanstveni interes: financijska ekonomija, bankarstvo, institucionalna ekonomija.Tel.:+37744 376 907.E-mail:valentintoci@gmail.com (osoba za kontakt). 